\section{Dr. Livija \\ Knaflič,}

Ana lleršič

Andragoški

center

Slovenije

\title{
PISMENOST - STANJE IN POTREBE NA SLOVENSKEM PODEŽELJU
}

\section{POVZETEK}

Mednarodna raziskava o pismenosti odraskih je pokazala, da so med najšbkejšmi skupinami na področju pismenosti odrasli, ki se ukvarjajo s kmetijstvom. Ta del prebivalstva (v Sloveniji obsega 24 odstotkov celotne populacije) ima tradicionalno nižjo porprečno stopnjo izobrazbe. se vodrasli dobi manj izobražuje, isakdanje dejawnosti pa ne zahtevijo zadostne rabe spretnusti. povezanih s pismenostjo, zato ina pozabljanje še močncjš učinek.

V prispevka je predstavljena poglobljena obdelava podatkov iz mednarodne raziskave o pismenosti odrastih ter podatkov iz drugih dweh virol, s katero smo seleli podrobneje preuciti značilnosti prebivalcev podeželja z vidika njihovih izobnaže valnih potreb na področju pismenosti. Ugotovljeno je, da ned kneckim prebivalstrom le 10 odstotkov odraslih dosega raven pismenosti, ki ustreza zahtevam današnjega časa. Primanjkljaji na področja pisnenosti se kažejo na wseh področjih njihovega delovanja: knerovanje, družina, prosti čas.

$Z$ vidika zuiševanja ravni pismenosti je usekakor pomemben podarek, da kažejo veliko pripranIjenost za pridobivanje spretnosti, povezanih s pismenostjo, med driggim tati za uporabo računalnika. Prav tako so podaki o usebinah, ki bi pritegnile adeležence s podeželja vizobražeranje, primerno izhodišče za načrtoranje ustreznih izobražetalnih ukrepou.

Ključne besede: pismenost odraslih, pismenost knečkega prebivaistra

$\mathbf{P}$ deležna posebne pozornosti na raziskovalnem področju, saj je postala z naglim razvojem informacijsko-komunikacijske tehnologije pomembna na vseh področjih človekovega delovanja. Pogostejša raba različnih spretnosti, povezanih s pismenostjo (branje, pisanje, računanje in uporaba računalnikal), v vsakdanjem življenju slehernega posimmeznika (računalniki in avtomati na delovnem mestu, mobilni telefoni, avtomati na javnih mestih, $\mathrm{v}$ gospodinjstvih itn.) je pripeljala do tega, da mi vsi bolj kot doslej potrebujemo določeno/ustrezno raven pismenosti za opravljanje svojih vlog. Slovenija si je s sodelovanjem v mednarodni raziskavi o pismenosti odraslih (International Adult Literacy Survey - IALS, 2000) pridobila koristne podatke o pismenosti odraslih v starosti od 16 do 65 let. Po eni strani so pridobljeni podatki omogočili ugotavljanje ravni pismenosti, ki ustreza zahtevam današnjega časa, in povezanosti različnih dejavnikov s pismenostjo posameznika. Po drugi strani pa je bila pomembnil primerjava dosežkov pismenosti odraslih med različnimi državami. Podatki o pismenosti odraslih $v$ Sloveniji so pokazali, da 77 odstotkov odraslih ne dosega mednarodnega povprečja, to 
je ralvni pismenosti, potrebne zal razumevanje in rabo pisnih informacij zal potrebe dejavnega vključcvanja v družbo. Vsaka od držav, ki so sodelovale $v$ raziskavi (večinoma članice OECD), sicer ima določen delež prebivalstva, ki je pod mednarodnim povprečjern, le da se v najrazvitejših dižavah ta delež giblje med 20 in 30 odstotki odraslih.

Ugotavljanje povezanosti med posameznimi dejalvniki in doseženo ravnjo pismenosti je (na slovenskem vzorcu) pokazalo, da se dosežki najbolj povezujejo $z$ doseženo stopnjo izobrazbe - naraščajo z višanjem stopnje izobrazbe. Primerjave mednarodnih podatkov o vplivu let šolanja na doseženo raven pisme nosti so pokazale, da je dvanajst let šolanja - nc glcde na šolski sistcm - tista mcja, ki zagotavljal ustrezno raven pismenosti. Dosežena spretnost je dovolj obstojna, manj je pozabljanja, predstavlja pa tudi ustrezno podlago za pridobivanje novih spretnosti, kot je znanje uporabe račcunalnika ali znanje tujega jezika. Starost je naslednji pomemben dejavnik: mlajš̌ odrasli dosegajo višje dosežke kot starejši odrasli, saj s starostjo upádajo psihofizične sposobnosti, starejši odrasli pa so $\mathrm{v}$ povprečju tudi manj izobraženi. Za Slovenijo se je izkazalo, da je izobrazba staršev tretji najpomembnejši dejavnik, povezan s pismenostjo odraslih. Odrasli so sicer izpostavljeni različnim vplivom po zaključku šolanja v delovnem okolju, med prijatelji itn., a je vpliv staršev in družinskega kroga $v$ naši družbi kljub temu izjemno močin. Dejavnosti v domačem okolju, povezane $z$ izobrazbo staršev, kot so življenjske razmere, način preživljanja prostega časa (bralne navade in bralna kultura), družinske vrednote itn., zaznamujejo posameznika za vse življenje.

Potrebal po ustrezni ravni pismenosti sc kaže tudi v vsakdanjem življenju na podeželju. Kmetje se srečujejo s spretnostmi, ki so povezane s pismenostjo, pri opravljanju tradicionalnih del, kot sta poljedelstvo ali živinoreja, saj morajo prebrati, razumeti in slediti različ- nim navodilom, izpolnjevati obrazce, računati in voditi stroške. $Z$ računalniško tehnologijo se srečujejo pri vodenju različnih evidenc (živinoreja, sadjarstvo, vinogradništvo) pa tudi na javnih mestih: na bankah (bankomati), $v$ zdravstvenih domovih, javnem prometu itd. Delo kmeta je poklic; kmetovanje prevzema značilnosti podjetništva, zahteva sledenje in prilagajanje spremembam, uvajanje novosti, pridobivanje dodatnih denarnih sredstev, vrednotenje dosežkov dela,
77 odstotkov odraslih Slovencev ne dosega mednarodnega povprečja funkcionalne pismenosti. iskanje tržnih priložnosti, možnosti za dopolnilne dejavnosti itn. Novosti v stroki, postopkih in zakonodaji ni mogoče usvojiti samo na osnovi dela in izkušenj, potrebno je tudi kakovostno znanje, ki predstavlja podlago za strokovne in poslovne odločitve. Pismenost, kot eno temeljnih orodij za pridobivanje novega znanja, jim omogoča lažje sledenje sodobnim tokovom v kmetijstvu, večjo uspešnost in posledično boljšo kakkovost življenja.

\section{RAZISKOVALNI IZSLEDKI}

Raziskava o pismenosti odraslih je pokazala, da so odrasli, ki se ukvarjajo s kmetijstvom, ena izmed podskupin, ki je dosegla nizke re zultate na preizkusu pismenosti. To nas je na Andragoškem centru Slovenije spodbudilo $k$ podrobnejšemu preučevanju značilnosti prebivalcev podeželja, ki se ukvarjajo s kmetijstvom, in to predvsem $z$ vidika njihovih izo-

Zaposlitveni položaj je četrti dejavnik, ki se povezuje z doseženo ravnjo pismenosti pri odraslih v Sloveniji. Mednarodna raziskava o pismenosti odraslih je pokazala, da so z vidika zaposlitvenega položaja med najšibkejšimi skupinami na področju pismenosti odrasli, ki se ukvarjajo s kmetijstvom. Zanje je značilno, da dosegajo najnižje ravni pismenosti na uporabljeni lestvici in da se manj kot drugi vključujejo v dejavnosti, povezane s pismenostjo, kot sta izobraževanje in vseživljenjsko učenje. 
braževalnih potreb na področju pismenosti. Podatke o njih smo črpali iz obsežne baze podatkov mednarodne raziskave o pismenosti odraslih, organizirali smo dve fokusni skupini in opravili telefonsko anketo.

\section{Izsledki raziskave o pismenosti odraslih za prebivalstvo podeželja}

$\mathrm{V}$ okviru mednarodne raziskave o pismenosti odraslih (IALS) je pismenost obravnavana kot sposobnost razumevanja in uporabe pisnih (tiskanih) informacij v vsakdanjih dejavnostih. Podatki o pismenosti so zbrani na podlagi vprašalnika o rabi pismenosti in preizkusa pismenosti, s katerim se je ocenjevalo predvsem razumevanje pisnih informacij $v$ besedilni (navodila, problemi z računskimi operacijami) ali grafični obliki (zemljevid, obrazec, razpredelnica). Stopnja pismenosti je opredeljena s petimi ravnmi: prvi dve sta pod mednarodnim povprečjem, tretja, četrta in peta raven pa so nad mednarodnim povprečjem ter zagotavljajo raven pismenosti, ki ustreza potrebam današnjega časa.

Pri podrobnejši obdelavi podatkov iz mednarodne raziskave o pismenosti smo želeli priti do populacije, ki jo tradicionalno imenujemo kmečko prcbivalstvo. To so ljudje, ki živijo na vasi in se preživljajo s kmetijstvorn.

Vzorec prebivalcev podeželja je sestavljalo 742 odraslih v starosti od 16 do 65 let. To je četrtina $(24,9 \%)$ vzorca in celotne populaci- je. Podatek se ujema s podatkom po zadnjem popisu prebivalstva (stanje 31. 12. 2002), po katerem v kmečkih naseljih pod 2000 prebivalcev živi 23,9 odstotka prebivalcev. V vzorcu je bilo 53 odstotkov moških in 47 odstotkov žensk, kar se nekoliko razlikuje od podatkov letopisa 2003 (5l odstotkov moških in 49 odstotkov žensk), a razlika ni statistično značilna. Prebivalce kmečkih naselij smo primerjali s prebivalci ostalih naselij tudi po stopnji izobrazbe in ugotovili, da je zanje značilna nižja stopnja povprečne izobrazbe, saj so ugotovljeni pomembno večji deleži odraslih z nižjo stopnjo izobrazbe (manj kot Oك̌, OŠ ali poklicna šola), in obratno, v ostalih naseljih je večji delež odraslih s srednjo stopnjo in višjimi stopnjami izobrazbe.

Primerjava dolžine šolanja pokaže, da imajo prebivalci $v$ pretežno mestnih naseljih za seboj $\vee$ povprečju 1,5 let daljšo dobo šolanja. Tovrstne razlike so bile že večkrat ugotovljene in so delno posledica dejstva, da ima kmečka mladina manj ugodne pogoje za šolanje ( $v$ povprečju slabši šolski uspeh, večja oddaljenost od izobraževalnih središč in slabši materialni pogoji $v$ družini), drugačno vrednotenje izobraževanja in nenazadnje tudi določeno možnost, da se preživlja $z$ neko dejavnostjo na kmetiji. $V$ ostalih naseljih pomeni šolanje pot do poklica in zaposlitve, ki jo velika večina išče in dobi izven doma.

Dosežena raven pismenosti prav tako ločuje

Tabela 1: Zaključena izobrazba

\begin{tabular}{|l|c|c|c|c|}
\hline Izobrazba & Kmečka naselja (\%) & Ostala naselja (\%) & Skupaj (\%) & LETOPIS 2003 \\
\hline Manj kot OŠ & 14 & 7 & 9 & 4 \\
\hline Osnovna šola & 28 & 21 & 22 & 24 \\
\hline Eno-, dvo- ali triletna poklicna SŠ & 27 & 25 & 26 & 28 \\
\hline Srednja šola & 20 & 31 & 28 & 29 \\
\hline Višja šola in več & 6 & 17 & 14 & 14 \\
\hline Skupaj (\%) & $\mathbf{1 0 0}$ & $\mathbf{1 0 0}$ & $\mathbf{1 0 0}$ & $\mathbf{1 0 0}$ \\
\hline sig(hi2)=0 & & & & \\
\hline
\end{tabular}

Vir: IALS, 2000. 
Tabela 2: Leto šolonja

\begin{tabular}{|l|c|c|c|c|c|}
\hline Vrsta naselja & $\mathbf{N}$ & Povprečje & $\begin{array}{c}\text { Standardni } \\
\text { odklon }\end{array}$ & Minimum & Maksimum \\
\hline Kmečka naselja pod 2000 prebivalci & 742 & 10,00 & 2,80 & 0 & 22 \\
\hline Ostala naselja & 2228 & 11,52 & 3,12 & 0 & 24 \\
\hline Skupaj & $\mathbf{2 9 7 0}$ & $\mathbf{1 1 , 1 4}$ & $\mathbf{3 , 1 1}$ & $\mathbf{0}$ & $\mathbf{2 4}$ \\
\hline
\end{tabular}

$\operatorname{sig}($ hi2 $)=0$

Vir: IALS, 2000

obe skupini, v kmečkih naseljih večina odraslih dosega nižje, podpovprečne ravni pismenosti. Medtem ko je $v$ celotnem vzorcu odraslih, zajetih v raziskavo, 77 odstotkov odraslih v Sloveniji po svojih dosežkih pod mednarodnim povprečjem (Literacy in the Information Age, 2000), jih je znotraj podskupine prebivalstvo kmečkih naselij pod mednarodnim povprečjem skoraj 90 odstotkov. Ti podatki so povezani s prej predstavljeno stopnjo izobrazbe, saj izobrazba, krajša od 12 let šolanja, ne zagotavlja ustrezne ravni pismenosti.

Na podlagi odgovorov na vprašalnik ${ }^{2}$ smo ugotovili, da se prebivalstvo podeželja manj udeležuje izobraževanja ali usposabljanja: of trenutka izvajanja raziskave se je $v$ zadnjih 12 Inesecih izobraževalo 20 odstotkov odraslih prebivalcev podeželja, medtem ko je delež pri vseh odraslih za enako obdobje 27 odstotkov. Obiskovanje kulturnih ustanov prav tako pomembno prispeva $\mathrm{k}$ ohranjanju ter nadaljnjem razvijanju pismenosti in pri primerjavi teh podatkov se prav tako kaže pomembna razlika med prebivalci podeželja in prebivalci ostalih naselij. Obiskovanje knjižnic je tesno povezano $z$ bralno kulturo, a je med kmečkim prebivalstvom manj prisotno kot med drugim prebivalstvom. Med prebivalci podeželja jih 69 odstotkov nikoli ne obišče knjižnice, med prebivalci ostalih naselij pa je takih le 49 odstotkov. Statistično značilne razlike so se pokazale tudi pri pogostosti obiskovanja drugih kulturnih ustanov (kino, gledališče, koncertne prireditve), je pa pri razpravi o teh podatkih treba upoštevati tudi oddaljenost kmečkih naselij od kulturnih središč, saj to prav gotovo vpliva na pogostost obiskovanja.

Dostopnost bralnega gradiva govori o bralni kulturi in bralnih navadah. Pri nas ima $v$ povprečju tri četrtine prebivalstva $\vee$ svojih domovih bralno gradivo, kot so dnevni časopisi (74\%), tedniki in revije ( $82 \%)$, leposlovne knjige $(86 \%)$, enciklopedije $(62 \%)$ in slovarji $(83 \%)$. Ob teh podatkih je treba povedati, da ima kmečko prebivalstvo manj gradiva kot nekmečko prebivalstvo, in lahko domnevamo, da je to povezano $z$ nekoliko boljšim gmotnim položajem, kakor tudi $z$ bralnimi navadami in načinom preživljanja prostega časi. Glede pogostosti rabe pisnih in bralnih spretnosti se

Graf 1: Ravni pismenosti prebivalcev kmečkih in ostalih naselij

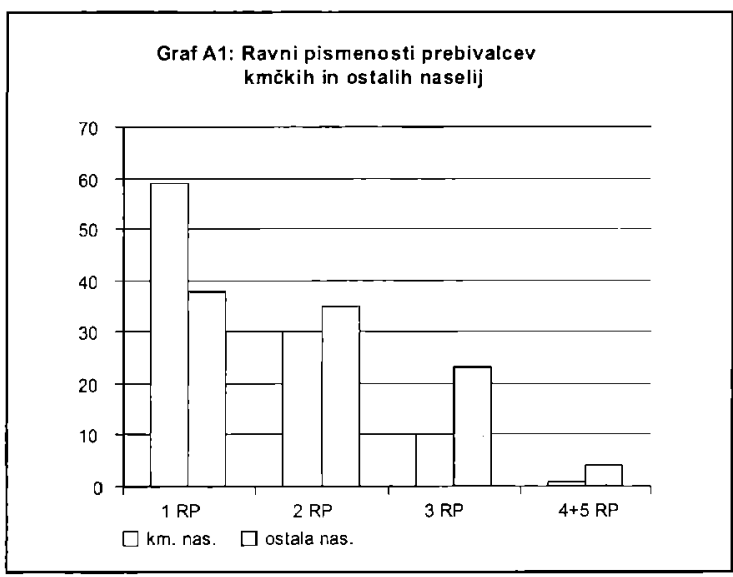


Pisnih spretnosti (pisanje pisem, dopisov) nikoli ne uporablja 59 odstotkov kmečkega prebivalstva, v nekmečkih naseljih pa 46 odstotkov odraslih. Dnevno bere 57 odstotkov odraslih v kmečkih naseljih, v nekmečkih pa 75 odstotkov odraslih.

je pokazala velika razlika med primerjanima skupinama prebivalstva.

Pogostost rabe posameznih spretnosti neposredno vpliva na njihovo ohranjanje. ( $V$ angleških besedilih o pismenosti pogosto omenjajo pregovor Use it or lose it! - Uporabljaj, če ne boš izgubil.) Narava dela v kmetijstvu, pa tudi drugi sociokulturni dejavniki, kot je način preživljanja prostega časá, pomembno vplivajo na to, v kakšni meri in za kaks̆ne priložnosti se bralne in pisne spretnosti uporabljajo. S tem lahko pojasnimo pridobljene podatke, ki kažcjo na redkcjšo vsakdanjo rabo pismenosti.

$\mathrm{Na}$ splošno se način življenja in pogostost rabe bralnih in pisnih spretnosti odraža tudi na pismenosti mlajših generacij prebivalstva. Otroci na podežclju so večinoma deležni manj spodbud, manjkrat vidijo odrasle brati in se $\mathrm{v}$ manjšem deležu naučijo brati in pisati pred vstopom v šolo (Knaflič, 2006). Pomemben podatek $\mathrm{z}$ vidika razvoja pismenosti je ta, da kaže kmečko prebivalstvo v vlogi staršev pomembno večjo pripravljenost sprejeti pomoč oz. svetovanje šolc in njenih strokovnih delavcev glede viste bralnega gradiva ter ocene otrokovih bralnih sposobnosti (94 odstotkov odraslih v kmečkih naseljih proti 85 odstotkov $\checkmark$ ostalih). Na podlagi tega lahko sklepamo, da obstaja zavedanjc o pomenu pismenosti za otrokov razvoj in pripravljenost narediti nekaj za otroke tudi na tem področju.

Če povzamemo predstavljene ugotovitve, je potrebno poudariti, da prebivalci podeželja predstavljajo eno četrtino prebivalstva. Dosežki pismenosti, ki so jo izkazali v mednarodni raziskavi pismenosti odraslih, kažejo, da le vsaki deseti med njimi dosega raven pismenosti, ki ustreza zahtevam današnjega časa. V povprečju imajo manj let šolanja, način življenja in dejavnosti, ki jih opravljajo, pa ne spodbujajo ohranjanja temeljnih spretnosti. Medgeneracijski prenos pismenosti poteka tudi $v$ njihovih družinah - raven pismenosti se prenaša iz roda v rod. Pomembna je ugotovitev, da kmečke družine kažejo večjo pripravljenost za sprejemanje zunanje pomoči, npr. s strani šolskih strokovnjakov.

\section{IZSLEDKI FOKUSNIH SKUPIN}

$\mathrm{Za}$ metodo fokusnih skupin smo se odločili, ker smo poleg globalnega pogleda $v$ problem pismenosti želeli priti do vpogleda $v$ razsežnosti problema pri posamezniku. Fokusni skupini, s skupaj 17 udeleženci, sta bili izpeljani $\checkmark$ prvi polovici leta 2005 v domačem okolju udeležencev. Pogovor je bil delno strukturiran s ključnimi vprašanji, po potrebi se je poglabljal z dodatnimi vprašanji.

$\mathrm{Na}$ podlagi odgovorov udeležencev lahko sklepamo, da se primanjkljaji na področju pismenosti kažejo na vseh področjih njihovega delovanja: kmetovanju, družinskem življenju in vzgoji otrok ter na osebni ravni (npr. skrbi za zdravje). Izpolnjevanje obrazcev je področje, pri katerem so udeleženci v veliki meri prepoznali svoje težave. Potrcba po uporabi računalnika se je razširila tudi med prebivalce podeželja, in sicer za vodenje evidenc o poslovanju kmetije, pogosto navajajo tudi pomoč otroku pri domačem delu za šolo.

Motivacija za nadaljnje izobraževanje je povezana $z$ izboljšanjem kmetovanja, udelě̌enke si želijo tudi vsebin, povezanih z gospodinjstvom, izdelovanjem predmetov domače obrti in ročnih del, predavanja o zdravem življenju in telovadbo.

Pridobljeni podatki govorijo o motiviranosti za izobraževanje, a je poleg vsebin treba upoštevati tudi pogoje, kot sta čas izvajanja (primerno je zimsko obdobje) in kraj izvajanja oziroma oddaljenost od kraja bivanja. 


\section{IZSLEDKI TELEFONSKE ANKETE}

Težave s pismenostjo, ki so bile nakazane $v$ okviru fokusnih skupin, smo preverjali tudi s pomočjo telefonske ankete. $Z$ anketo smo zajeli 300 anketirancev iz vse Slovenije, ki živijo $v$ kmečkih naseljih.

Prepoznavanje primanjkljajev smo ugotavljali z vprašanjem o morebitnih težavah pri izpolnjevanju obrazcev. Iz odgovorov je razvidno, da se z obrazci vsakodnevno srečujejo (le $3 \%$ vprašanih ni izpolnjevalo obrazcev) in da jih je 83 odstotkov potrebovalo določeno mero pomoči (14 \% vprašanih ni potrebovalo pomoči). Obdelava podatkov po starosti in letih šolanja je pokazala, da potrebujejo mlajši prebivalci podeželja manj pomoči kot starejši. Leta šolanja, kot je bilo že večkrat dokazano, prispevajo k ohranjanju pismenosti; z dolžjno šolanja se zmanjšuje obseg pomoči, ki jo potrebujejo posamezniki pri izpolnjevanju obrazcev. Med obrazci, s katerimi se srečujejo, je najzahtevnejši obrazec za subvencije v kmetijstvu. Za pomoč se največ obračajo na družinske člane, prijatelje in sorodnike, obračajo se tudi na urade po plačano ali brezplačno pomoč.

Glede na obseg problema izpolnjevanja ob- razcev nas je zanimalo tudi, ali bi se anketiranci udeležili kakšnega usposabljanja za izpolnjevanje obrazcev. Odgovori kažejo, da bi se jih od vseh vprašanih 42 odstotkov odločilo za usposabljanje, 19 odstotkov je bilo neodločnih (odgovor: morda), 39 odstotkov pa se jih usposabljanja ne bi udeležilo. Pri odločanju o usposabljanju ima največjo težo vsebina usposabljanja, sledijo oddaljenost kraja izvedbe od kraja bivanja, cena in trajanje usposabljanja. Raba računalnika se razširja

42 odstotkov prebi-
valcev podeželja bi
se udeležilo uspo-
sabljanja za izpol-
njevanje obrazcev.
tudi na podeželje. Računalnike ima 61 odstotkov gospodinjstev, a to še ne pomeni, da ga tudi uporabljajo. Manj kot polovica imetnikov računalnika tega tudi uporablja (44\%). Uporabljajo ga za delo (73\%) in v prostem času (73\%). Zanimivo je, da so otroci odraslim precejšnja spodbuda za rabo računalnika in 59 odstotkov anketirancev navaja, da uporabljajo računalnik skupaj z otrokom.

Zanimalo nas je tudi, katere izobraževalne vsebine so privlačne za kmečko prebivalstvo. Nenazadnje je zviševanje ravni pismenosti povezano $z$ določenimi potrebami in vsebinami. Predvsem nas je zanimalo, ali bi bilo

Graf 2: Izbrane izobraževalne vsebine

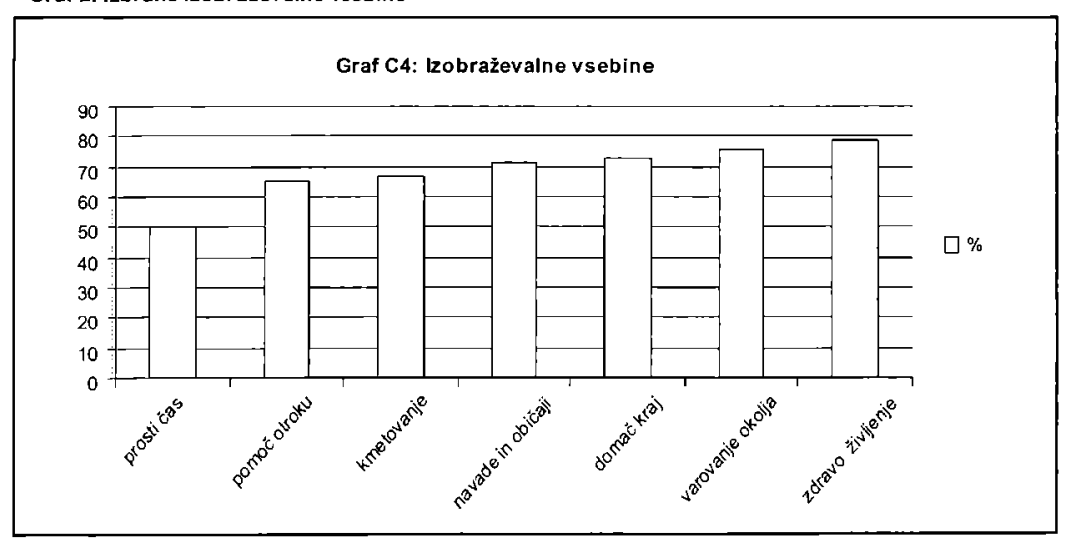


Kmetijska svetovalna služba organizira štiri sklope izobraževanj: Slovenski kmetijsko okoljski program (SKOP), Varstvo pri delu, Priprava za Nacionalne poklicne kvalifikacije in razna neformalna izobraževanja. V okviru Skopa kmetje prejemajo plačila za odpravljanje zaraščanja, ozelenitev njivskih površin, ekološko kmetovanje, planinsko pašo, ohranjanje habitatov ogroženih vrst ptic idr. Drug sklop izobraževanja (Varstvo pri delu) je obvezen za vse, ki vodijo kmetije. Do Nacionalne poklicne kvalifikacije pride preko Kmetijske svetovalne službe vsako leto približno 100 posameznikov, izbirajo pa lahko med petimi kvalifikacijami.

možno povezati zviševanje ravni pismenosti s področjem trajnostnega razvoja. Trajnostni razvoj je razmeroma obsežen pojem, ki se obravnava $z$ ekonomskega in človekoljubnega vidika. Svetovna komisija za okolje in razvoj (1987) ga opredeljuje kot razvoj, ki omogoča »Zadovoljevanje potreb sedanjih rodov, ne da bi ogrožal možnosti prihodnjih rodov za zadovoljevanje njihovih (v Barbič, 2005, str. 16).

Pri doseganju ciljev, ki temeljijo na načelih trajnostnega razvoja, ina izobraževanje temeljno vlogo, zlasti izobraževanje odraslih. Kljub razmeroma širokemu pojmovanju trajnostnega razvoja je prav podeželje področje, na katerem se lahko sledi načelom trajnostnega razvoja $z$ različnih vidikov: gospodarskega, okoljskega, družbenega in kulturnega. Delež odgovorov po posameznih vsebinah je predstavljen $v$ grafu 2 .

Izpostaviti je treba razmeroma visok delež pri vseh predlaganih vsebinah. Podatki govorijo o motiviranosti za izobraževanje in pestrosti interesov kmečkega prebivalstva, nenazadnje tudi o njihovi ozaveščenosti. Približno tri četrtine anketirancev kaže zanimanje za zdravo življenje, varstvo okolja in spoznavanje domačega kraja. Izbrane vsebine so blizu vsebinam, ki podpirajo trajnostni razvoj in so primerne/uporabne za zvišcvanje ravni pismenosti.

\section{OBSTOJEČA IZOBRAŽEVALNA PONUDBA ZA PODEŽELSKO PREBIVALSTVO}

Poleg podatkov o ravni pismenosti in o izobraževalnih potrebah na področju pismenosti pri kmečkem prebivalstvu nas je zanimalo tudi, kakšna je izobraževalna ponudba za podeželsko prebivalstvo $v$ letu 2005. Z izobraževanjem te ciljne skupine se $v$ Sloveniji ukvarja kar lepo stevilo izobraževalnih organizacij: kmetijske šole, Kmetijska svetovalna služba, razvojne agencije, društva in zasebne organizacije (ki se ukvarjajo z izobraževanjem odraslih) ter ljudske univerze.

Kmetijske, živilske in gozdarske sole v Sloveniji izobražujejo in usposabljajo dijake za osnovne poklice od nižje poklicne do srednje tehniške ravni, in te programe ponujajo tudi za odrasle. Znanja, ki jih udeleženci usvajajo, so zelo raznolika; slaščičarstvo, pekarstvo, šivanje, mesnopredelovalna dejavnost, domača obrt, vinarstvo, veterinarstvo ...

Kmetïska svetovalna služba je ena izmed strokovnih služb Kmetijsko gozdarske zbornice Slovenije in je zelo aktivna pri izobraževanju in usposabljanju podeželskega prebivalstva. Kmetijska svetovalna služba organizira različne vrste izobraževanj, odkar je bila leta $1990^{7}$ ustanovljena, število programov, ki jih ponuja, pa se vsako leto povečuje. $V$ večini primerov so to neformalna, brezplačna izobraževanja, po zaključku katerih udeleženci dobijo potrdila, ki jih lahko uporabijo v morebitnem nadaljnjem izobraževanju za priznavanje določenih vsebin. Izobraževanja potekajo intenzivno od decembra do marca - $v$ času, ko je na kmetiji manj dela kot običajno.

Vsebine neformalnih izobraževanj se spreminjajo glede na potrebe in želje podeželskega prebivalstva. Svetovalci Kmetijske svetoval- 
ne službe se ob obiskih kmetij seznanjajo s tem, katere vsebine bi kmetom pomagale pri delu in na podlagi tega pripravljajo delavnice. Vsebine so zclo specifične, npr. Analiza vzorcev in oblikovanje cene mleka, Vodenje kletarskih evidenc, Prilagoditev reje perutnine novim zahtevam EU ...

Razvojne agencije obstajajo v vsaki slovenski regiji. Sodelujejo pri pripravi in $v$ nekaterih primerih tudi izvajanju Regionalnega razvojnega programa, sodelujejo v različnih evropskih projektih, namenjenih razvoju podeželja, se usmerjajo $v$ aktiviranje ekonomskih potencialov podeželja, delajo na področju zaposlovanja, razvijajo skrb za okolje in ohranjanje tradicij, skratka, njihove aktivnosti so v prvi vrsti namenjene razvijanju podjetnosti podeželskega prebivalstva, zato so izobraževanja, ki jih organizirajo, usmerjena $v$ ta cilj.

Zasebne organizacije za izobraževanje odraslih in liudske univerze, ki se usmerjajo $v$ izobraževanje podeželskega prebivalstva, pripravljajo različne vrste izobraževanj oz. usposabljanj. Večinoma so ta usposabljanja namenjena spodbujanju podjetnosti pri kınetih, izobraževanju o možnostih financiranja različnih aktivnosti, načinih trženja lastnih izdelkov ipd. Ljudske univerze tudi izobražujejo podeželsko prebivalstvo, vendar v okviru svoje redne izobraževalne ponudbe (usposabljanja za pridobitev poklica, usposabljanja za prosti čas, jezikovni tečaji ...).

Društva so zelo aktivna pri izobraževanju podeželskega prebivalstva, npr. Društvo za razvoj slovenskega podeželja, društva podeželskih žena, Zveza slovenske podeželske mladine itn. Med vsemi doslej naštetimi organizacijarmi, ki usposabljajo podeželsko prebivalstvo, so društva edina, ki organizirajo tudi delavnice, ki niso usmerjene »le v razvijanje podjetništva, seznanjanje $z$ novimi pravili ali pridobitvijo poklica. Sicer se posvečajo tudi vsebinam, specifičnim za podeželje (npr. razvoj ekoturizma, ogled dobrih praks), vendar dajejo velik poudarek seznanjanju kmečkega prebivalstva $\mathrm{z}$ vsebinami, ki niso izključno podeželske (npr. računalništvo, slikanje na svilo, seminarji na temo večkulturnosti), poleg tega namenjajo veliko pozornosti tudi druženju in izmenjavi izkušenj.

\section{ZAKLJUČEK}

$\checkmark$ raziskavi pridobljeni podatki in pregled izobraževalne ponudbe so nam omogočili vpogled v stanje in potrebe slovenskega podeželja na področju pismenosti. Podeželskemu prebivalstvu so sicer na voljo različna izobraževanja, vendar so večinoma usmerjena $v$ kmetijske vsebine in načine dela na kmetiji ter seznanjanju z različnimi predpisi. Največ delavnic, namenjenih tudi drugim sestavinam izobraževanja (pomembnosti druženja, izmenjavanju medosebnih izkušenj), organizirajo različna društva, namenjena podeželskemu prebivalstvu. Programov, ki bi bili namenjeni posebej za izboljšanje pismenosti, ni oz. jih pri našem raziskovanju nismo našli.

Za razvoj s pismenostjo povezanih spretnosti je pomembno, da izhajajo iz potreb udeležencev, se povezujejo z vsebinami, ki so privlačne za udeležence, in da usposabljanje poteka tako, da zagotavlja pridobivanje potrebnih/ uporabnih spretnosti in odpravljanje primanjkljajev za vsakega posameznega udeleženca. Dosedanje izkušnje $z$ razvojem programov za zviševanje ravni pismenosti in raziskovalne ugotovitve o pismenosti na podeželju smo združili $v$ izobraževalnem programu Izzivi podeželja, ki je del projekta Usposabljanje za življenjsko uspešnost in ga bomo po možnosti predstavili $v$ eni naslednjih številk Andragoških spoznanj.

\section{LITERATURA}

Barbič, A. (1995). Kulturna identiteta slovenskega podežclja. V Kovačič, M. (ur.) (1995), Celovit razvoj podeželja. Ljubljana: Biotehnična fakulteta.

Barbič, A. (2005). Izzivi in priložnosti podeželja. Ljubljana: Založba FDV. 
Knaflič, L. idr, (2001). Temeljno znanje in spretnosti mladih, brezposelnih in staršev šolskih otrok. Riziskovalro poročilo. Ljubljana: Andragoški center Slovenije. Knatlič, L. (2006). Pismenost na podeželju. Raziskovalno poročilo. Ljubljana: Andrugoški center Siovenije. Kovačič. M. (ur.) (1995). Celovit razvoj podežclja. Ljubljana: Biotehnična lakulteta.

Literacy in the Intormation Age (2000). Pariz: OECD.

Scott, W. (ut:) (2004). Key Issues in Sustainable Development and Lear'ning. London: Routledge Falme:

Statistične informacije, št. 92/2003. Ljubljana: SURS. Statistični letopis 2003. Ljubljana: Statistični ulaad RS.

'Statistichi arad RS (SURS) y letopisilt od leta 2003 uporablja nowo delitey naselij na mesma in nemesma, pri čemer wo mestha opredeljena na podlagi šrith kriterije: nemesna usa druga naselja. ki ne urwezajo opredelinvi mestnega naselja (več "Statistične informacije. 5. 92/2003).

2 Podrobnejši podarki v raziskowalnem poročiln: Knaflič, L. (2006). Pismenost na podě̃elju. Ljubljana: Andragoski temter Slotenije.

${ }^{3}$ Začetki kmetijskega svetovanja segajo v Stoveniji 19. stolerje. Kmerijska swetovalna shuzba je bila ustanowijena 1. januarja 1990. zadijo reorganizacijo je dozivela novembia 2000. ko je prešla vestaro Kmetijske gozdarske bormice. 